\title{
The Impact of Covid-19 on Saudi Arabian Female Students: An Application of the CES-D Depression Scale
}

\author{
Dr. Siddiqua Aamir \\ Dr. Carmen Winkel \\ Core Humanities \& Social Science, \\ Prince Mohammad Bin Fahd University, \\ Al Khobar 31952, Kingdom of Saudi Arabia
}

DOI: https://doi.org/10.36941/jesr-2021-0oo3

\section{Abstract}

SARS-CoV-2 (Severe acute respiratory syndrome coronavirus type 2) is a new beta coronavirus that was identified as the trigger of COVID-19 disease in early 2020. Our study designed to survey the female undergraduate students at a private university in Saudi Arabia to assess the degree of psychological impact during the initial stages of the lockdown. During the first weeks of the outbreak in Saudi Arabia and the government-initiated lockdown, we conducted an online survey with 400 female undergraduate students in Saudi Arabia. The psychological impact was assessed by using the Center for Epidemiologic Studies Depression Scale (CES-D). Our study shows that over the four weeks students showed clearly a change in the overall mental health and mood of our students.

Keywords: Covid-19, Depression, Female Students, Online-Learning

\section{Introduction}

Since the first case of the novel coronavirus disease 2019 (COVID-19) was diagnosed in the city of Wuhan in December 2019 the virus spread globally and reached almost every country on the planet. The SARS-CoV-2 virus has spread very efficiently from person to person by droplet infection in the short time after its initial discovery in December 2019 as the causative agent of pneumonia. On December 31, 2019, the WHO country office in China was informed about an accumulation of pneumonia in Wuhan. On January 7,2020 , the Chinese authorities identified the novel coronavirus SARS-CoV-2 as the cause of the disease. Since then, the number of cases of SARS-CoV-2 infections has risen dramatically worldwide. In September 2020, 9 months after the first recorded outbreak of the pandemic, John Hopkins University estimates that 30.5 million people are infected worldwide and a total of around 950.00o people have died (John Hopkins University of Medicine, 2020). In the fight against the corona pandemic, curfews or curfew restrictions are currently in force around the globe affecting one billion people (Lai et al., 2020; Wu \& McGoogan, 2020; Baig, Khaleeq, Ali, \& Syeda, 2020). After the initial outbreak in China, the pandemic spread to Western-Europe with Italy and Spain the worse affected countries. After strict curfews had greatly slowed down the spread of Covid-19 in 
Europe, infection rates rose dramatically in other regions. In particular, the United States, India and Brazil developed into the new epicentres of the disease despite all countermeasures.

The coronavirus SARS-CoV-2 is a new virus that has not yet been detected in humans before the initial outbreak in China at the end of 2019. Coronaviruses $(\mathrm{CoV})$ can cause diseases in humans that range from mild colds to more severe and fatal illnesses (Fisher \& Heymann, 2020).

In the vast majority of cases of Covid-19 are mild. The probability of severe and even fatal disease progression increases with age and existing pre-existing conditions. The individual risk cannot be determined from the epidemiological/statistical data. Even without pre-existing conditions, the course of the disease can be severe or even life-threatening even for young, healthy people. The risk of longterm consequences is not yet assessable. In spring 2020, more and more countries realized that the corona pandemic is a serious crisis that must be combated with rigorous measures. Even states such as the United Kingdom and the USA, where governments had initially reacted cautiously to the spread of the virus, adopted drastic measures such as travel restrictions, closing borders, curfews and the introduction of compulsory face masks in public (Nussbaumer-Streit et al., 2020; Anderson, Heesterbeek, Klinkenberg, \& Hollingsworth, 2020).

While each country is developing its strategies to slow down the spread of the virus, the closure of educational institutions was one of the first measures taken in most states. With the outbreak of the global pandemic, 1.5 trillion students worldwide were affected who were no longer able to attend classes due to quarantine measures (Galea, Merchant, \& Lurie, 2020).

In Saudi Arabia, schools, colleges and similar educational institutions were closed on March 15 and teaching continued in the form of online classes. These measures were taken after the first cases of Covid-19 were detected in the Kingdom and were accompanied by the closure of all international borders (Awaji, 2020; Al Saidi et al., 2020). In the following weeks, social distancing measures, mandatory face coverings, curfews and a complete five-day lockdown were enforced throughout the country. Besides, 24-hour lockdowns were implemented and enforced for neighbourhoods and cities that had large outbreaks of Covid-19. Furthermore, all shopping malls and recreational facilities were close, restaurants only allowed to take away orders and residents were not allowed to leave their neighbourhoods. All these measures were enforced by the police and military. Furthermore, the Hajj and Umrah pilgrimage was only allowed for a very limited number of pilgrims and under very strict social distancing measures (Ebrahim \& Memish, 2020).

As described by many other international studies the social distancing measures and the complete shutdown of public life has a big impact on the psychological health of children and adults. Studies have shown that the pandemic causes increased levels of anxiety, depression and the deterioration of the psychological wellbeing (Alkhamees et al., 2020; Brooks et al., 2020; Sahu, 2020) of students all ages. The focus of our study is how the lockdown in Saudi Arabia has affected the psychological situation of our students.

\section{Literature Review}

Several studies have already looked into the psychosocial effects of quarantine measures and identified various effects. These included depressions, anxiety, sleeping problems, loneliness and social isolation. It was pointed out that the duration of the quarantine and the intensity of the lockdown measures have a decisive influence on the psychosocial effects on an individual (Röhr, 2020). Early studies conducted in some countries that were severely affected by Covid-19 in January and February had pointed to serious psychological problems (Elmer, Mepham \& Stadtfeld, 2020; Wang, 202ob; Lee, Jobe, Mathis, \& Gibbons, 2020). Study participants had high anxiety and moderate symptoms of depression (Cullen, Gulati, \& Kelly, 2020). In addition to many studies on the effects of Covid-19 on the overall population in various countries, the impact of the pandemic on the psychological situation of students was also investigated very early on.

For college students, the pandemic has increased fears about the future, financial insecurity and social isolation. Studies in the USA have shown that with the loss of part-time jobs and the closure of 
university dormitories, students were facing existential problems like financial shortcomings and the threat of homelessness especially in expensive metropolitan areas (John, 2020). Similar studies on effects of Covid-19 on the psychological condition of students have been conducted for China, Spain, Italy, Switzerland and many other countries (Cao et al., 2020; Odriozola-González, Planchuelo-Gómez, Irurtia, \& de Luis-García, 2020; Elmer, Mepham \& Stadtfeld, 2020; D'Agostino, Demartini, Cavallotti, \& Gambini, 2020).

Several studies have indicated, that many people suffer from stress and depression even after the relaxation or lifting of initial restrictions (Wang, 202ob). The main drivers of the increase in stress continue to be the burden of changes in work or education and the affliction of limited social life. Some studies have shown that psychological problems in the past (before the corona crisis) increase the risk of developing severe depressive symptoms during the corona crisis (Brooks, 2020; Lee, Jobe, Mathis, \& Gibbons, 2020; Cullen, Gulati, \& Kelly, 2020; Qiu et al., 2020). Various studies have emphasized that there is little evidence that the corona crisis is leading to depression in large numbers of previously healthy people (Pieh, Budimir, \& Probst, 2020).

The real problem, however, is that the care and condition of people with an existing diagnosis is getting worse. Also, there are indications that domestic violence is a much greater problem in the corona crisis than usual: a representative study in Germany concluded that five per cent of those surveyed currently feel threatened by their partner - and of those who were in quarantine at the time of the survey, the figure was almost eight per cent. Nearly six per cent of the participants in quarantine stated that they had had physical confrontations with their partner in the past seven days - compared with only 0.9 per cent of those who were not in quarantine (COSMO, 2020). Women and girls belong to disadvantaged groups in all societies and are therefore particularly hard hit by the pandemic and its consequences. This leads to immediate health consequences as well as to longer-term economic consequences. Besides, times of crisis are particularly dangerous for women, as they are less well protected from domestic and sexualized violence (Cousins, 2020).

\section{Method}

We used an online survey that was sent out to our students during the Spring Semester 2019/2020 via email. Students were encouraged to answer the questions; all answers were received anonymously. The participants of this survey included $420(n=420)$ female students from Prince Mohammad Bin Fahd University. All students were undergraduate students, the average age of the students was 21 years. All of these students were enrolled in the two authors classes during the lockdown. We started the survey after the first week of lockdown and online teaching and continued the survey for three more weeks, until the end of the semester. For the survey we used the Center for Epidemiologic Studies Depression Scale (CES-D) which is one of the most popular and widespread scales to measure depressive symptoms (Lewinsohn, Seeley, Roberts, \& Allen, 1997; Carleton et al., 2013). This widely used self-report measure is being used to assess symptoms of depression in a general population (Gubash, 2000).

The scale has a 4 factor and 20 item structure, where symptoms for depression are being assessed through self-statements (e.g. I could not get going). Ratings are bases on a 4-point scale ranging from (rarely or none of the time to 4 (most or all the time) (Carleton et al., 2013; Jiang et al., 2019).

\section{Results}

Based on a 4-point Likert scale with the anchors being 1. Rarely or none of the time (less than 1 day), 2. Some or a little of the time (1-2 days), 3. Occasional or a moderate amount of time (3-4 days), 4. Most or all of the time (5-7 days. The questionnaire was scored by totalling the item scores and then dividing by 20 , producing an index score ranging from 1 to 4 . An index score of 4 indicated the subject was experiencing extreme low mood, and an index score of 1 suggested that the subject was experiencing no symptoms of low mood.

During the first week of the lockdown and online-classes, $13 \%$ students obtained the index score 
4, 22\% index score of 3, 30\% index score 2, while 35\% acquired index score 1 . Index score was got by totalling the item scores of each student on the Depression Scale (CES-D) survey questionnaire and then dividing by 20 .

The mean index score of the students in the survey questionnaire was 2.13. It was acquired by adding up the total index score of all the students $(\mathrm{N}=420)$ on survey questionnaire and dividing by 420. During the second week of the lockdown, $15 \%$ of students obtained the index score $4,20 \%$ index score of $3,38 \%$ index score 2 , while $27 \%$ acquired index score 1 .

The mean index score of the students on the survey questionnaire was 2.23 .

For the third week, $20 \%$ of students obtained the index score 4, 32\% index score of 3, 39\% index score 2 , while $9 \%$ acquired index score 1 . The mean index score of the students on the survey questionnaire was 2.6

In week $436 \%$ of the students obtained the index score $4,14 \%$ index score of $3,28 \%$ index score 2, while 22 acquired index score 1 . The mean index score of the students in the survey questionnaire was 2.6. Certain items showed an especially strong development throughout the study. For example, on item 6: I felt depressed, 50 (12\%) participants obtained the index score 4 in week 1, but it increased to $104(25 \%)$ in week 4 . Item 7 : I felt that everything I did was an effort, initially, $92(22 \%)$ had an index score of 4 , but in the following weeks it increased to 130 (31\%); Item 10. I felt fearful, from $142(34 \%)$ in the first to 210 (50\%) in week 4; Item 11: My sleep was restless, 130 (31\%) participants acquired index score 4 , but it incrementally increased to $164(39 \%)$ in the last week of the survey; score on item 14: I felt lonely, also showed a gradual increase in the numbers from $63(15 \%)$ in the first week towards 122 $(29 \%)$ in the last week; Item 17 . I had crying spells, numbers rose from 101 (24\%) to 122 (29\%); Item 18. I felt sad, a drastic change was observed during the preceding weeks from 54(13\%) to $151(36 \%)$.

\section{Discussion}

The findings of current studies are in consistence with the observations of researches carried out recently on the pandemic COVID-19 and its social, psychological and economic well-being on the affected. In a recent study conducted in Saudi Arabia on the current pandemic designed to survey the general population in Saudi Arabia to assess the degree of psychological impact during the pandemic; researchers recruited 1160 respondents of the public of Saudi Arabia and conducted an online survey using a snowballing sample technique. The psychological impact and mental health status were highlighted using the Impact of Event Scale-Revised (IES-R), and the Depression, Anxiety, and Stress Scale (DASS-21). 23.6\% of participants reported moderate or severe psychological impact of the outbreak, $28.3 \%$ reported moderate to severe symptoms of depression, and $24 \%$ of anxiety. Results further established that during the early onset of the pandemic COVID-19 in Saudi Arabia, almost onefourth of the sampled general population experienced moderate to the severe psychological impact. (Alkhamees et al., 2020).

Another extensive study that provided the first empirical evidence, using incremental validity analyses, also established that the corona-phobia construct could be considered as a unique predictor of psychological distress during the COVID-19 crisis, 453 adult workers in the U.S. completed an online survey. The vulnerability factors among participants were assessed by using test package; John and Srivastava's (1999) 8-item scale was administered to assess the personality trait of neuroticism, Salkovskis, Rimes, Warwick, and Clark's (2002) 18-item inventory was utilized to determine health anxiety, Lee's (2020) 5-item scale was used for measuring coronaphobia, Abdel-Khalek's (1998) singleitem death anxiety scale was used to measure psychological distress, and to determine the level of depression and generalized anxiety, Kroenke et al.'s (2009) 2-item scales were used. The statistical analysis showed that a significant number of participants experienced severe levels of clinical based psychological distress (Lee et al., 2020). 


\section{Conclusion}

The surveys showed that over the four weeks, the proportion of female students who scored 4 on the index tripled. From $13 \%$ in the first week to $36 \%$ in the fourth week. The overall acquired index-score also changed, from one in the first week to 2.6 in the last week of the survey. Especially the answers for some items on the scale indicating a change in the overall mental health and mood of our students. Our study has shown, that the pandemic causes increased levels of anxiety, depression and the overall deterioration of the psychological wellbeing of our students. This finding is consistent with the results of studies from other countries, as well as with a larger, representative study of the Saudi population as a whole. Since the lockdown measures in the Kingdom have not yet been completely lifted, it can be assumed that the psychological situation of the female students will continue to deteriorate. Although no more curfews have been announced, universities and all other educational institutions remain closed. In addition, the country has not yet opened its international borders, making international travel impossible.

More longitudinal studies on a larger sample of students are required to determine the longlasting emotional impact of this deadly virus. Further researches can provide an insight into negative biological, psychological, social, and economic effects in general on overall population; and in specific on the academic performance, family functioning and social engagements of the younger generation.

China and Italy, initially the two countries hardest hit by Covid-19, started very early to offer psychological help to those affected (Liu et al., 2020; D'Agostino, Demartini, Cavallotti, Gambini, 2020). In both countries, strict, month-long lockdowns of the population were imposed on the most affected areas (Wuhan and Lombardy). The psychological effects observed here show how strongly the measures of social distancing, quarantine and fear of infection have affected the mental health of broad sections of the population. Both countries have also shown that many of these effects can be mitigated with targeted offers of help. It is hoped that other countries that are currently severely affected, such as the United States, India, South Africa and Brazil, will find similar ways to mitigate the psychological effects of this pandemic on its citizens.

\section{References}

Al Saidi, A. M. O., Nur, F. A., Al-Mandhari, A. S., El Rabbat, M., Hafeez, A., \& Abubakar, A. (2020). Decisive leadership is a necessity in the COVID-19 response. The Lancet, 396(10247), 295-298.

Alkhamees, A. A., Alrashed, S. A., Alzunaydi, A. A., Almohimeed, A. S., \& Aljohani, M. S. (2020). The psychological impact of COVID-19 pandemic on the general population of Saudi Arabia. Comprehensive Psychiatry, 152192. https://doi.org/10.1016/j.comppsych.2020.152192

Anderson, R. M., Heesterbeek, H., Klinkenberg, D., \& Hollingsworth, T. D. (2020). How will country-based mitigation measures influence the course of the COVID-19 epidemic?. The Lancet, 395(10228), 931-934.

Awaji, M.A. (2020). Pandemic of Coronavirus (COVID-19) in Saudi Arabia. Journal of Research E Method in Education 20(4), 43-47 doi:1097907388-1004044347.

Baig, A. M., Khaleeq, A., Ali, U., \& Syeda, H. (2020). Evidence of the COVID-19 virus targeting the CNS: tissue distribution, host-virus interaction, and proposed neurotropic mechanisms. ACS chemical neuroscience, 11(7), 995-998.

Brooks, S. K., Webster, R. K., Smith, L. E., Woodland, L., Wessely, S., Greenberg, N., \& Rubin, G. J. (2020). The psychological impact of quarantine and how to reduce it: a rapid review of the evidence. The Lancet, 395, 912920. https://doi.org/10.1016/So140-6736(20)3046o-8

Cao, W., Fang, Z., Hou, G., Han, M., Xu, X., Dong, J., \& Zheng, J. (2020). The psychological impact of the COVID-19 epidemic on college students in China. Psychiatry Research, 112934.

Carleton, R. N., Thibodeau, M. A., Teale, M. J., Welch, P. G., Abrams, M. P., Robinson, T., \& Asmundson, G. J. (2013). The centre for epidemiologic studies depression scale: a review with a theoretical and empirical examination of item content and factor structure. PloS one, 8(3), e58067 https://doi.org/10.1371/journal.pone.0058067

Cousins, S. (2020). COVID-19 has "devastating" effect on women and girls. The Lancet, 396(10247), 301-302 doi:https://doi.org/10.1016/So140-6736(20)31679-2 
COVID-19 Snapshot Monitoring (COSMO), https://projekte.uni-erfurt.de/cosmozozo/cosmo-analysis.html (20.9.2020).

Cullen, W., Gulati, G., \& Kelly, B. D. (2020). Mental health in the Covid-19 pandemic. QJM: An International Journal of Medicine, 113(5), 311-312.

D'Agostino, A., Demartini, B., Cavallotti, S., \& Gambini, O. (2020). Mental health services in Italy during the COVID19 outbreak. The Lancet Psychiatry, 7(5), 385-387. doi:https://doi.org/10.1016/S2215-0366(20)30133-4

Ebrahim, S. H., \& Memish, Z. A. (2020). Saudi Arabia's drastic measures to curb the COVID-19 outbreak: temporary suspension of the Umrah pilgrimage. Journal of Travel Medicine, 27(3), 29-39.

Elmer, T., Mepham, K., \& Stadtfeld, C. (2020). Students under lockdown: Comparisons of students' social networks and mental health before and during the COVID-19 crisis in Switzerland. Plos one, 15(7), e0236337.

Fisher, D., \& Heymann, D. (2020). Q\&A: The novel coronavirus outbreak causing COVID-19. BMC medicine, 18(1), 13 .

Galea, S., Merchant, R. M., \& Lurie, N. (2020). The mental health consequences of COVID-19 and physical distancing: The need for prevention and early intervention. JAMA internal medicine, 180(6), 817-818. doi:10.1001/jamainternmed.2020.1562

Ghubash, R., Daradkeh, T. K., Al Naseri, K. S., Al Bloushi, N. B. A., \& Al Daheri, A. M. (20oo). The performance of the Center for Epidemiologic Study Depression Scale (CES-D) in an Arab female community. International Journal of Social Psychiatry, 46(4), 241-249.

Islam, M. S., Ferdous, M. Z., \& Potenza, M. N. (2020). Panic and generalized anxiety during the COVID-19 pandemic among Bangladeshi people: An online pilot survey early in the outbreak. Journal of Affective Disorders (74) https://doi.org/10.1016/j.janxdis.2020.102268

Jiang, L., Wang, Y., Zhang, Y., Li, R., Wu, H., Li, C., ... \& Tao, Q. (2019). The reliability and validity of The Center for Epidemiologic Studies Depression Scale (CES-D) for Chinese university students. Frontiers in psychiatry, 10, 315 https://doi.org/10.3389/fpsyt.2019.00315

John Hopkins University of Medicine, COVID-19 Dashboard by the Center for System Science and Engineering, https://coronavirus.jhu.edu/map.html, (20.9.2020).

John, A. (March 20, 2020). Increased anxiety and depression top college students concerns in coronavirus concerns, https://www.latimes.com/california/story/2020-03-25/college-students-anxiety-depression-coronavirussurvey, (accessed August 2, 2020).

Konstantopoulou, G., \& Raikou, N. (2020). Clinical evaluation of depression in university students during quarantine due to covid-19 pandemic. European Journal of Public Health Studies, 3(1).

Lai, C. C., Shih, T. P., Ko, W. C., Tang, H. J., \& Hsueh, P. R. (2020). Severe acute respiratory syndrome coronavirus 2 (SARS-CoV-2) and coronavirus disease-2019 (COVID-19): the epidemic and the challenges. International Journal of Antimicrobial Agents, 105924.

Lee, J. (2020). Mental health effects of school closures during COVID-19. The Lancet Child E Adolescent Health, 4(6), 421. doi:https://doi.org/10.1016/S2352-4642(20)30109-7

Lee, S. A., Jobe, M. C., Mathis, A. A., \& Gibbons, J. A. (2020). Incremental validity of coronaphobia: Coronavirus anxiety explains depression, generalized anxiety, and death anxiety. Journal of anxiety disorders, (74) 102268. https://doi.org/10.1016/j.janxdis.2020.102268

Lewinsohn, P. M., Seeley, J. R., Roberts, R. E., \& Allen, N. B. (1997). Center for Epidemiologic Studies Depression Scale (CES-D) as a screening instrument for depression among community-residing older adults. Psychology and aging, 12(2), 277.

Liu, S., Yang, L., Zhang, C., Xiang, Y. T., Liu, Z., Hu, S., \& Zhang, B. (2020). Online mental health services in China during the COVID-19 outbreak. The Lancet Psychiatry, 7(4), e17-e18. doi:https://doi.org/10.1016/S2215$0366(20) 30077-8$

Nussbaumer-Streit, B., Mayr, V., Dobrescu, A. I., Chapman, A., Persad, E., Klerings, I. \& Gartlehner, G. (2020). Quarantine alone or in combination with other public health measures to control COVID-19: a rapid review. Cochrane Database of Systematic Reviews, (9), 1-75.

Odriozola-González, P., Planchuelo-Gómez, Á., Irurtia, M. J., \& de Luis-García, R. (2020). Psychological effects of the COVID-19 outbreak and lockdown among students and workers of a Spanish university. Psychiatry Research, 113-118.

Pieh, C., Budimir, S., \& Probst, T. (2020). Mental health during COVID-19 lockdown: A comparison of Austria and the UK. Available at SSRN 3592372, 3-23.

Qiu, J., Shen, B., Zhao, M., Wang, Z., Xie, B., \& Xu, Y. (2020). A nationwide survey of psychological distress among Chinese people in the COVID-19 epidemic: implications and policy recommendations. General psychiatry, 33(2). 
Rajkumar, R. P. (2020). COVID-19 and mental health: A review of the existing literature. Asian journal of psychiatry, 102066 https://doi.org/10.1016/j.ajp.2020.102066

Röhr, S., Müller, F., Jung, F., Apfelbacher, C., Seidler, A., \& Riedel-Heller, S. G. (2020). Psychosoziale Folgen von Quarantänemaßnahmen bei schwerwiegenden Coronavirus-Ausbrüchen: ein Rapid Review. Psychiatrische Praxis, $47(4), 179$.

Sahu, P. (2020). Closure of universities due to Coronavirus Disease 2019 (COVID-19): impact on education and mental health of students and academic staff. Cureus, $12(4)$.

Tang, W., Hu, T., Hu, B., Jin, C., Wang, G., Xie, C., ... \& Xu, J. (202o). Prevalence and correlates of PTSD and depressive symptoms one month after the outbreak of the COVID-19 epidemic in a sample of homequarantined Chinese university students. Journal of affective disorders, 1-7 https://doi.org/10.1016/j.jad.2020.05.009

Wang, Z. H., Yang, H. L., Yang, Y. Q., Liu, D., Li, Z. H., Zhang, X. R., ... \& Wang, X. M. (2020a). Prevalence of Anxiety and Depression symptom, and the Demands for Psychological Knowledge and Interventions in college students during COVID-19 epidemic: A large Cross-Sectional Study. Journal of Affective Disorders https://doi.org/10.1016/j.jad.2020.06.034

Wang, Z. H., Yang, H. L., Yang, Y. Q., Liu, D., Li, Z. H., Zhang, X. R., ... \& Wang, X. M. (202ob). Prevalence of Anxiety and Depression symptom, and the Demands for Psychological Knowledge and Interventions in college students during COVID-19 epidemic: A Large Cross-Sectional Study. Journal of Affective Disorders, 188-193 https://doi.org/10.1016/j.jad.2020.06.034

Wu, Z., \& McGoogan, J. M. (2020). Characteristics of and important lessons from the coronavirus disease 2019 (COVID-19) outbreak in China: summary of a report of 72314 cases from the Chinese Center for Disease Control and Prevention. Jama, 323(13), 1239-1242.

\section{Appendix A}

Table 1: Survey Data Week 1

\begin{tabular}{|c|c|c|c|c|c|}
\hline No. & Items & \begin{tabular}{|c|}
$\begin{array}{c}\text { Rarely or none } \\
\text { of the time (less } \\
\text { than } 1 \text { day) }\end{array}$ \\
\end{tabular} & $\begin{array}{c}\text { Some or a little } \\
\text { of the time (1-2 } \\
\text { days) }\end{array}$ & $\begin{array}{c}\text { Occasional or a } \\
\text { moderate amount } \\
\text { of time ( } 3-4 \text { days) }\end{array}$ & $\begin{array}{c}\text { Most or all of } \\
\text { the time (5-7 } \\
\text { days) }\end{array}$ \\
\hline 1. & $\begin{array}{l}\text { I was bothered by things that usually don't } \\
\text { bother me. }\end{array}$ & $97(23 \%)$ & $202(48 \%)$ & $88(21 \%)$ & $34(8 \%)$ \\
\hline 2. & I did not feel like eating; my appetite was poor. & $189(45 \%)$ & $126(30 \%)$ & $63(15 \%)$ & $42(10 \%)$ \\
\hline 3. & $\begin{array}{l}\text { I felt that I could not shake off the blues even } \\
\text { with help from my family or friends. }\end{array}$ & $168(40 \%)$ & $122(29 \%)$ & $92(22 \%)$ & $38(9 \%)$ \\
\hline 4. & I felt I was just as good as other people. & $71(17 \%)$ & $126(30 \%)$ & $147(35 \%)$ & $76(18 \%)$ \\
\hline 5 & $\begin{array}{l}\text { I had trouble keeping my mind on what I was } \\
\text { doing. }\end{array}$ & $84(20 \%)$ & $156(37 \%)$ & $92(22 \%)$ & $88(21 \%)$ \\
\hline 6. & I felt depressed & $118(28 \%)$ & $160(38 \%)$ & $92(22 \%)$ & $50(12 \%)$ \\
\hline 7. & I felt that everything I did was an effort. & $50(12 \%)$ & $143(34 \%)$ & $135(32 \%)$ & $92(22 \%)$ \\
\hline 8. & I felt hopeful about the future. & $50(12 \%)$ & $173(41 \%)$ & $105(25 \%)$ & $92(22 \%)$ \\
\hline 9. & I thought my life had been a failure. & $227(54 \%)$ & $109(26 \%)$ & $63(15 \%)$ & $21(5 \%)$ \\
\hline 10. & I felt fearful. & $139(33 \%)$ & $139(33 \%)$ & $92(22 \%)$ & $50(12 \%)$ \\
\hline 11. & My sleep was restless & $50(12 \%)$ & $126(30 \%)$ & $114(27 \%)$ & $130(31 \%)$ \\
\hline 12. & I was happy & $80(19 \%)$ & $126(30 \%)$ & $130(31 \%)$ & $84(20 \%)$ \\
\hline 13. & I talked less than usual. & $143(34 \%)$ & $143(34 \%)$ & $84(20 \%)$ & $50(12 \%)$ \\
\hline 14. & I felt lonely & $130(31 \%)$ & $143(34 \%)$ & $84(20 \%)$ & $63(15 \%)$ \\
\hline 15. & People were unfriendly & $252(60 \%)$ & $105(25 \%)$ & $42(10 \%)$ & $21(5 \%)$ \\
\hline 16. & I enjoyed life & $84(20 \%)$ & $130(31 \%)$ & $109(26 \%)$ & $97(23 \%)$ \\
\hline 17. & I had crying spells & $189(45 \%)$ & $130(31 \%)$ & $71(17 \%)$ & $30(7 \%)$ \\
\hline 18. & I felt sad & $80(19 \%)$ & $181(43 \%)$ & $105(25 \%)$ & $54(13 \%)$ \\
\hline 19. & I felt that people dislike me & $252(60 \%)$ & $93(22 \%)$ & $50(12 \%)$ & $25(6 \%)$ \\
\hline 20. & I could not get "going" & $139(33 \%)$ & $155(37 \%)$ & $76(18 \%)$ & $50(12 \%)$ \\
\hline
\end{tabular}




\section{Appendix B}

Table 2: Survey Data Week 2

\begin{tabular}{|c|c|c|c|c|c|}
\hline No. & Items & $\begin{array}{c}\begin{array}{c}\text { Rarely or none } \\
\text { of the time (less } \\
\text { than } 1 \text { day) }\end{array} \\
\end{array}$ & $\begin{array}{c}\text { Some or a little } \\
\text { of the time (1-2 } \\
\text { days) }\end{array}$ & $\begin{array}{c}\text { Occasional or a } \\
\text { moderate amount } \\
\text { of time (3-4 days) }\end{array}$ & $\begin{array}{c}\text { Most or all of } \\
\text { the time (5-7 } \\
\text { days) }\end{array}$ \\
\hline 1. & $\begin{array}{l}\text { I was bothered by things that usually don't } \\
\text { bother me. }\end{array}$ & $92(22 \%)$ & $210(50 \%)$ & $97(23 \%)$ & $21(5 \%)$ \\
\hline 2. & I did not feel like eating; my appetite was poor. & $160(38 \%)$ & $134(32 \%)$ & $88(21 \%)$ & $38(9 \%)$ \\
\hline $3 \cdot$ & $\begin{array}{l}\text { I felt that I could not shake off the blues even } \\
\text { with help from my family or friends. }\end{array}$ & $168(40 \%)$ & $143(34 \%)$ & $71(17 \%)$ & $38(9 \%)$ \\
\hline 4. & I felt I was just as good as other people. & $71(17 \%)$ & $139(33 \%)$ & $139(33 \%)$ & $71(17 \%)$ \\
\hline 5. & $\begin{array}{l}\text { I had trouble keeping my mind on what I was } \\
\text { doing. }\end{array}$ & $80(19 \%)$ & $160(38 \%)$ & $100(24 \%)$ & $80(19 \%)$ \\
\hline 6. & I felt depressed & $114(27 \%)$ & $160(38 \%)$ & $84(20 \%)$ & $63(15 \%)$ \\
\hline 7. & I felt that everything I did was an effort. & $54(13 \%)$ & $198(47 \%)$ & $109(26 \%)$ & $59(14 \%)$ \\
\hline 8. & I felt hopeful about the future. & $76(18 \%)$ & $126(30 \%)$ & $147(35 \%)$ & $71(17 \%)$ \\
\hline 9. & I thought my life had been a failure. & $168(40 \%)$ & $122(29 \%)$ & $100(24 \%)$ & $30(7 \%)$ \\
\hline 10. & I felt fearful. & $126(30 \%)$ & $143(34 \%)$ & $109(26 \%)$ & $42(10 \%)$ \\
\hline 11. & My sleep was restless & $88(21 \%)$ & $76(18 \%)$ & $134(32 \%)$ & $122(29 \%)$ \\
\hline 12. & I was happy & $50(12 \%)$ & $152(36 \%)$ & $168(40 \%)$ & $50(12 \%)$ \\
\hline 13. & I talked less than usual. & $92(22 \%)$ & $189(45 \%)$ & $76(18 \%)$ & $63(15 \%)$ \\
\hline 14. & I felt lonely & $164(39 \%)$ & $92(22 \%)$ & $76(18 \%)$ & $88(21 \%)$ \\
\hline 15. & People were unfriendly & $197(47 \%)$ & $168(40 \%)$ & $30(7 \%)$ & $25(6 \%)$ \\
\hline 16. & I enjoyed life & $71(17 \%)$ & $118(28 \%)$ & $155(37 \%)$ & $76(18 \%)$ \\
\hline 17. & I had crying spells & $202(48 \%)$ & $104(25 \%)$ & $84(20 \%)$ & $30(7 \%)$ \\
\hline 18. & I felt sad & $71(17 \%)$ & $182(43 \%)$ & $104(25 \%)$ & $63(15 \%)$ \\
\hline 19. & I felt that people dislike me & $243(58 \%)$ & $92(22 \%)$ & $55(13 \%)$ & $30(7 \%)$ \\
\hline 20. & I could not get "going" & $147(35 \%)$ & $147(35 \%)$ & $76(18 \%)$ & $50(12 \%)$ \\
\hline
\end{tabular}

\section{Appendix C}

Table 3: Survey Data Week 3

\begin{tabular}{|c|c|c|c|c|c|}
\hline No. & Items & $\begin{array}{c}\begin{array}{c}\text { Rarely or none } \\
\text { of the time (less } \\
\text { than } 1 \text { day) }\end{array} \\
\end{array}$ & $\begin{array}{c}\text { Some or a little } \\
\text { of the time (1-2 } \\
\text { days) }\end{array}$ & \begin{tabular}{|c|}
$\begin{array}{c}\text { Occasional or a } \\
\text { moderate amount } \\
\text { of time (3-4 days) }\end{array}$ \\
\end{tabular} & \begin{tabular}{|c}
$\begin{array}{c}\text { Most or all of } \\
\text { the time (5-7 } \\
\text { days) }\end{array}$ \\
\end{tabular} \\
\hline 1. & $\begin{array}{l}\text { I was bothered by things that usually don't bother } \\
\text { me. }\end{array}$ & $84(20 \%)$ & $176(42 \%)$ & $126(30 \%)$ & $34(8 \%)$ \\
\hline 2. & I did not feel like eating; my appetite was poor. & $147(35 \%)$ & $134(32 \%)$ & $63(15 \%)$ & $76(18 \%)$ \\
\hline 3. & $\begin{array}{l}\text { I felt that I could not shake off the blues even with } \\
\text { help from my family or friends. }\end{array}$ & $118(28 \%)$ & $202(48 \%)$ & $71(17 \%)$ & $30(7 \%)$ \\
\hline 4. & I felt I was just as good as other people. & $97(23 \%)$ & $168(40 \%)$ & $71(17 \%)$ & $84(20 \%)$ \\
\hline 5. & $\begin{array}{l}\text { I had trouble keeping my mind on what I was } \\
\text { doing. }\end{array}$ & $38(9 \%)$ & $164(39 \%)$ & $134(32 \%)$ & $84(20 \%)$ \\
\hline 6. & I felt depressed & $63(15 \%)$ & $151(36 \%)$ & $84(20 \%)$ & $122(29 \%)$ \\
\hline 7. & I felt that everything I did was an effort. & $50(12 \%)$ & $151(36 \%)$ & $105(25 \%)$ & $114(27 \%)$ \\
\hline 8. & I felt hopeful about the future. & $54(13 \%)$ & $202(48 \%)$ & $84(20 \%)$ & $80(19 \%)$ \\
\hline 9. & I thought my life had been a failure. & $155(37 \%)$ & $114(27 \%)$ & $97(23 \%)$ & $54(13 \%)$ \\
\hline 10. & I felt fearful. & $105(25 \%)$ & $143(34 \%)$ & $76(18 \%)$ & $97(23 \%)$ \\
\hline 11. & My sleep was restless & $105(25 \%)$ & $76(18 \%)$ & $105(25 \%)$ & $134(32 \%)$ \\
\hline 12. & I was happy & $46(11 \%)$ & $198(47 \%)$ & $134(32 \%)$ & $42(10 \%)$ \\
\hline 13. & I talked less than usual. & $97(23 \%)$ & $134(32 \%)$ & $105(25 \%)$ & $84(20 \%)$ \\
\hline 14. & I felt lonely & $104(25 \%)$ & $126(30 \%)$ & $63(15 \%)$ & $126(30 \%)$ \\
\hline 15. & People were unfriendly & $176(42 \%)$ & $147(35 \%)$ & $84(20 \%)$ & $13(3 \%)$ \\
\hline 16. & I enjoyed life & $84(20 \%)$ & $126(28 \%)$ & $126(30 \%)$ & $84(20 \%)$ \\
\hline 17. & I had crying spells & $186(44 \%)$ & $100(24 \%)$ & $104(25 \%)$ & $30(7 \%)$ \\
\hline 18. & I felt sad & $63(15 \%)$ & $151(36 \%)$ & $114(27 \%)$ & $92(22 \%)$ \\
\hline 19. & I felt that people dislike me & $176(42 \%)$ & $151(36 \%)$ & $71(17 \%)$ & $21(5 \%)$ \\
\hline 20. & I could not get "going" & $126(30 \%)$ & $151(36 \%)$ & $100(24 \%)$ & $42(10 \%)$ \\
\hline
\end{tabular}




\section{Appendix D}

Table 4: Survey Data Week 4

\begin{tabular}{|c|c|c|c|c|c|}
\hline No. & Items & \begin{tabular}{|c|}
$\begin{array}{c}\text { Rarely or none } \\
\text { of the time (less } \\
\text { than } 1 \text { day) }\end{array}$ \\
\end{tabular} & $\begin{array}{c}\text { Some or a little } \\
\text { of the time (1-2 } \\
\text { days) }\end{array}$ & \begin{tabular}{|c|}
$\begin{array}{c}\text { Occasional or a } \\
\text { moderate amount } \\
\text { of time (3-4 days) }\end{array}$ \\
\end{tabular} & \begin{tabular}{|c|}
$\begin{array}{c}\text { Most or all } \\
\text { of the time } \\
\text { (5-7 days) }\end{array}$ \\
\end{tabular} \\
\hline 1. & $\begin{array}{l}\text { I was bothered by things that usually don't bother } \\
\text { me. }\end{array}$ & $164(39 \%)$ & $164(39 \%)$ & $92(22 \%)$ & o \\
\hline 2. & I did not feel like eating; my appetite was poor. & $76(18 \%)$ & $193(46 \%)$ & $104(25 \%)$ & $46(11 \%)$ \\
\hline 3. & $\begin{array}{l}\text { I felt that I could not shake off the blues even with } \\
\text { help from my family or friends. }\end{array}$ & $164(39 \%)$ & $134(32 \%)$ & $76(18 \%)$ & $46(11 \%)$ \\
\hline 4. & I felt I was just as good as other people. & $126(30 \%)$ & $139(33 \%)$ & $92(22 \%)$ & $63(15 \%)$ \\
\hline 5. & I had trouble keeping my mind on what I was doing. & $63(15 \%)$ & $147(35 \%)$ & $147(35 \%)$ & $63(15 \%)$ \\
\hline 6. & I felt depressed & $47(11 \%)$ & $222(53 \%)$ & $47(11 \%)$ & $104(25 \%)$ \\
\hline 7. & I felt that everything I did was an effort. & $63(15 \%)$ & $164(39 \%)$ & $63(15 \%)$ & $130(31 \%)$ \\
\hline 8. & I felt hopeful about the future. & $46(11 \%)$ & $202(48 \%)$ & $109(26 \%)$ & $63(15 \%)$ \\
\hline 9. & I thought my life had been a failure. & $151(36 \%)$ & $147(35 \%)$ & $46(11 \%)$ & $76(18 \%)$ \\
\hline 10. & I felt fearful. & $30(7 \%)$ & $182(43 \%)$ & $134(32 \%)$ & $76(18 \%)$ \\
\hline 11. & My sleep was restless & $76(18 \%)$ & $76(18 \%)$ & $104(25 \%)$ & $164(39 \%)$ \\
\hline 12. & I was happy & $63(15 \%)$ & $134(32 \%)$ & $164(39 \%)$ & $59(14 \%)$ \\
\hline 13. & I talked less than usual. & $126(30 \%)$ & $126(30 \%)$ & $105(25 \%)$ & $63(15 \%)$ \\
\hline 14. & I felt lonely & $126(28 \%)$ & $76(18 \%)$ & $104(25 \%)$ & $122(29 \%)$ \\
\hline 15. & People were unfriendly & $164(39 \%)$ & $147(35 \%)$ & $63(15 \%)$ & $46(11 \%)$ \\
\hline 16. & I enjoyed life & $92(22 \%)$ & $147(35 \%)$ & $134(32 \%)$ & $46(11 \%)$ \\
\hline 17. & I had crying spells & $116(28 \%)$ & $182(43 \%)$ & $76(18 \%)$ & $46(11 \%)$ \\
\hline 18. & I felt sad & $92(22 \%)$ & $116(28 \%)$ & $59(14 \%)$ & $151(36 \%)$ \\
\hline 19. & I felt that people dislike me & $222(53 \%)$ & $46(11 \%)$ & $76(18 \%)$ & $76(18 \%)$ \\
\hline 20. & I could not get "going" & $104(25 \%)$ & $116(28 \%)$ & $124(29 \%)$ & $76(18 \%)$ \\
\hline
\end{tabular}

